African Crop Science Journal by African Crop Science Society is licensed under a Creative Commons Attribution 3.0 Uganda License. Based on a work at www.ajol.info/ and www.bioline.org.br/cs DOI: http://dx.doi.org/10.4314/acsj.v24i1.5

\title{
GENETIC ANALYSIS OF YIELD AND FLESH COLOUR IN SWEETPOTATO
}

\author{
S.I.M. NAIDOO ${ }^{1,2}$, S.M. LAURIE ${ }^{2}$, D.A. ODENY ${ }^{3,4}$, B.J. VORSTER ${ }^{1}$, W.M. MPHELA ${ }^{2}$, \\ M.M. GREYLING ${ }^{2}$ and B.G. CRAMPTON ${ }^{5}$ \\ ${ }^{1}$ Department of Plant Production and Soil Science, University of Pretoria, Pretoria, South Africa \\ ${ }^{2}$ Agricultural Research Council-Vegetable and Ornamental Plants (ARC-VOP), Private bag X293, \\ Pretoria, 0001, South Africa \\ ${ }^{3}$ ARC-Biotechnology Platform, Pretoria, South Africa \\ ${ }^{4}$ International Crop Research Institute of Semi-Arid Tropics, Nairobi, Kenya \\ ${ }^{5}$ Department of Plant Science, University of Pretoria, Pretoria, South Africa \\ Corresponding author: slaurie@ arc.agric.za
}

(Received 3 September, 2015; accepted 26 February, 2016)

\begin{abstract}
Pre-breeding information on the inheritance mechanism of important sweetpotato (Ipomoea batatas L.) agronomic traits is still limited. This study aimed at assessing the inheritance of five sweetpotato agronomic traits, viz. marketable fresh root yield (MFRY) and number (MNR), total fresh root yield (TFRY) and number (TNR) and root $\beta$-carotene content (RBCC). A $5 \times 5$ full diallel was performed and $F_{1}$ progenies, evaluated in two environments alongside the parents. The data were subjected to ANOVA and DiallelSAS-05 Griffing's method 1. Simple Sequence Repeat (SSR) based genetic distance and cluster analysis were performed on the parental lines using Jaccard's coefficient and the unweighted pair group method with arithmetic averages (UPGMA). Significant differences $(\mathrm{P}<0.01)$ were detected among the genotypes for MFRY, MNR, TFRY, TNR and RBCC. Significant general and specific combining ability $(\mathrm{P}<0.01)$ effects were observed for all five traits. Additive gene action was predominantly involved in the inheritance of these traits. High broad sense heritability values were observed for the four yield parameters and for RBCC. The Jaccard's similarity coefficient indicated moderate to low genetic similarity distances among the parents, implying high diversity. The knowledge on the inheritance and diversity of the parental genotypes enables more effective choice of parents in breeding improved varieties.
\end{abstract}

Key Words: $\beta$-carotene, combining ability, heritability, root yield, genetic diversity

\section{RÉSUMÉ}

Les informations préliminaires sur le mode de transmission des caractères agronomiques importants chez la patate douce (Ipomoea batatas L.) sont encore très limitées. Cette étude vise à évaluer la transmission de cinq traits agronomiques chez la patate douce. viz. Le rendement de tubercules fraîches à valeur marchande (MFRY) et leur nombre (MNR), le rendement total de tubercules frais (TFRY) et leur nombre (TNR), de même que la teneur en $\beta$-carotene des tubercules (RBCC). Une série de croisement diallel 5 x 5 avec croisements réciproques a été réalisée et les descendants de génération $\mathrm{F} 1$ ont été évalués ensemble avec les parents dans deux environnements. Les données collectées ont été soumises à une analyse de variances et à une analyse DiallelSAS-05 méthode 1 de Griffing. Les distances génétiques basées sur des Répétitions de Séquences Simples (SSR) a été calculées et une classification numérique à été réalisée sur les lignées parentales. Le coefficient de Jaccard et la méthode des pairesgroupes non pondérés avec la moyenne arithmétique (UPGMA) ont été utilisées à cet effet. Des différences significatives $(\mathrm{P}<0.01)$ ont été observées entre les génotypes pour MFRY, MNR, TFRY, TNR et RBCC. Des effets significatifs de l'habileté de combinaison générale $(\mathrm{P}<0.01)$ ont été observés sur tous les 5 traits. L'effet 
additif des gènes était prédominant. Des valeurs d'héritabilité au sens large ont été observées pour quatre paramètres de rendements en tubercules et pour RBCC. Le coefficient de similarité de Jaccard a indiqué une des distances de similarité génétique faibles ou modérées entre les parents, ce qui suggère une grande diversité. Les connaissances sur le mode transmission et la diversité des lignées parentales permet des choix plus efficients des parents à utiliser dans un programme d'amélioration génétique.

Mots Clés: $\beta$-carotene, habileté de combinaison, héritabilité, rendement en tubercules, diversité génétique

\section{INTRODUCTION}

Sweetpotato (Ipomoea batatas L.) is the third most important root and tuber crop in the world, following potato (Solanum tuberosum L.) and cassava (Manihot esculenta Crantz). Over 95\% of the world's sweetpotato is produced in developing countries, where it is considered to be a staple food crop (FAOSTAT, 2012). The root crop is very popular among poor farmers, and has the ability to grow in conditions with limited agricultural inputs and labour requirements (Lebot, 2009). Sweetpotato roots and leaves combine nutritional quality with high levels of edible energy, which is needed to combat food insecurity and malnutrition (Bovell-Benjamin, 2007). The incidence of vitamin A deficiency (VAD) in Africa and Asia is worrying. South Africa alone has reported that $43.6 \%$ of children between 1 and 5 years old (Shisana et al., 2013) and $27 \%$ of women at the reproductive age (Labadarios et al., 2007) are vitamin A deficient.

As a cheaper and sustainable measure to combat and prevent VAD, orange-fleshed sweetpotato (OFSP) cultivars rich in $\beta$-carotene (precursor of pro-vitamin A) are being used to mitigate micronutrient deficiency in Africa (Nagujja and Yanggen, 2005; Van Jaarsveld et al., 2005; Laurie and Faber, 2008) and West Asia (Mukherjee and Ilangantileke, 2001). Although bio-fortification of sweetpotato in South Africa through conventional breeding has resulted in the release of superior cultivars, the pre-breeding information on the inheritance mechanism of the essential traits is still limited.

Due to self- and cross-incompatibility in sweetpotato, caused by incompatibility alleles (Shiotani and Kawase, 1987), polycross and diallel crossing are the mating designs commonly used in the breeding (Hwang et al., 2002; Laurie et al., 2009) combined with genetic analysis (Mwanga et al., 2002; Chiona, 2010; Shumbusha et al., 2014; Musembi et al., 2015). Diallel analysis is a breeding tool that makes use of direct crosses between selected genotypes, in order to obtain information on the combining abilities, which are then used to predict the performance of the progenies (Buteler et al., 2002; Bertan et al., 2007). Diallel analysis has been used in sweetpotato to determine the general combining ability (GCA) and specific combining ability (SCA) of yield, flesh colour, dry matter content and harvest index in the root (Chiona, 2010; Tumwegamire et al., 2011; Shumbusha et al., 2014).

The understanding of the genetic relationship between parental lines is particularly important in the selection of lines capable of combining and creating superior progeny in a hybrid combination. To maximise successful improvement and genetic gains in the breeding programmes, genetic variation is necessary for effective selection of parental genotypes to be included in the breeding programs (Tumwegamire et al., 2011).

Both morphological and molecular analyses have been used in the past, to select parental lines that would maximise the desired traits in the resulting progenies. However, molecular markers remain the most reliable method, as these are not affected by the environment. Simple Sequence Repeat (SSR) markers have become tools of choice for many crops, due to their analytical resolution (Edward and McCouch, 2007), easy scoring and interpretation of results, especially in crops with high ploidy levels such as sweetpotato (hexaploid, 2n=6x=90; Jones, 1965).

Although over 1600 EST-based SSR markers have been identified for sweetpotato (Schafleitner et al., 2010), only a limited number of SSR markers have been tested and used in diversity analysis of sweetpotato by various authors (Zhang et al., 1999; Hwang et al., 2002; Gichuru et al., 2005; 
Elameen et al., 2008; Veasey et al., 2008; Karuri et al., 2010; Tumwegamire et al., 2011; Gwandu et al., 2012).

In this study SSR markers were used to establish genetic relationships among selected sweetpotato parental lines that were subsequently used in a $5 \times 5$ diallel cross. Furthermore, the combining abilities of the parents and heritability of yield and flesh colour in sweetpotato root were determined across two environments.

\section{MATERIALS AND METHODS}

Parental lines and crossing. Eight sweetpotato breeding lines, commonly used by the Agricultural Research Council-Vegetable and Ornamental Plants (ARC-VOP), Roodeplaat Experimental Station (25.604 p S 28.345 p E). sweetpotato breeding programme were selected according to yield and flesh colour attributes (Table 1). The parental lines were hand-crossed in all possible ways. Due to cross incompatibility between some genotypes, a full diallel was obtained from five parental genotypes (Monate, Ndou, Khano, Resisto and W-119). These generated 20 first generation families $\left(F_{1}\right)$. The $F_{1}$ seeds were scarified by immersion in $98 \%$ sulphuric acid for 20 to 25 minutes, in order to remove the hard seed coating to enhance germination (Montelaro and Miller, 1951). The seeds were thoroughly rinsed with running tap water and then placed on wet filter paper, in petridishes kept in the dark for 48 hours to sprout. These were then planted in trays filled with 50:50 mixture of Hygromix growing medium (Hygrotech, South Africa) and vermiculite. At three to four nodes stage, the seedlings were transplanted to the field for bulking of vine material.

Field evaluation. Five individuals from each cross combination were selected from the bulking plots, based on the plant vigour and best chance of survival. Field trials were established at two diverse agro-ecologies viz. Roodeplaat (North of Pretoria, Gauteng; 25.604 p S 28.345 p E) and Owen Sithole College of Agriculture (Empangeni, Kwa-Zulu Natal; 28. 725 p S 31.898 p E) in South Africa in 2013 (Table 2). The experiments were conducted in a randomised complete block design (RCBD), with three replications. Standard agronomic practices for sweetpotato production were followed (Van den Berg and Laurie, 2004). NPK (1:0:1) and 12\% Calsiphos (Petrow Agri, South Africa) were broadcast in the field at a rate of $500 \mathrm{~kg} \mathrm{ha}^{-1}$, potassium chloride at $200 \mathrm{~kg} \mathrm{ha}^{-1}$ and $28 \%$ limestone ammonium nitrate (LAN, 28) (Petrow Agri, South Africa) at a rate of $120 \mathrm{~kg}$ $\mathrm{ha}^{-1}$.

Irrigation during the growing season was performed once to twice a week, depending on the rainfall. Each plot contained five cuttings, with a spacing of $30 \mathrm{~cm} \mathrm{x} 1 \mathrm{~m}$. Border plants were added at each end of the plot.

At maturity (approximately 165 days after transplanting), data were collected on total fresh root mass and number (TFRY and TNR), and marketable fresh root mass and number (MFRY and MNR). Marketable roots were considered as roots between 100 and $1200 \mathrm{~g}$ and with a regular shape. The root $\beta$-carotene content (RBCC) was estimated by cutting the fresh root longitudinally, comparing the flesh colour to the colour chart used by Burgos et al. (2009), and recording the corresponding $\beta$-carotene value indicated by the colour chart.

Statistical analysis. The data were subjected to analysis of variance (ANOVA) using GenStat ${ }^{\circledR}$ $16^{\text {th }}$ Edition (VSN International Ltd., Hempstead). General combining ability (GCA) and specific combining ability (SCA) were estimated following Model 1 of Griffing (1956), including the parents, $\mathrm{F}_{1}$ progenies and reciprocal effects, in DiallelSAS05 (Statistical Analysis Software Institute; Zhang et al., 2004). DiallelSAS-05 uses a linear model for estimating combining ability, which aportions the total genotypic variance into variance components (Zhang et al., 2004), including GCA, SCA and reciprocal effects. The model is represented by Equation 1:

$$
\begin{aligned}
& Y_{i j k m l}=\mu+S_{i}+B_{j(i)}+G C A_{K}+G C A_{l} \\
& +S C A_{k l}+S * G C A_{i k}+S * G C A_{i l}+ \\
& S * G C A_{i k l}+R_{i j k l m} \quad \ldots \ldots \ldots \ldots \ldots . . . . . E q u a t i o n ~ 1
\end{aligned}
$$

Where: 
$Y_{i j k l m}=$ the $m$ th observation of the $j$ th block for $k l$ th cross in the $i$ th site; $\mu$ is the overall mean; $S i$ $=$ the th fixed site (environment) effect $i=l$ to $t$; $B_{j(i)}=$ the fixed effect of the $j$ th block within the $i$ th site, $j=l$ to $b ; G C A_{k}, G C A_{l}=$ the random general combining ability (GCA) effect of the $k$ th female or $l$ th more Normally, Independently Distributed (NID) ( $\left(0, \sigma_{G}^{2}\right), k, l=1$ to $p$ and $k<l$; $S C A_{k l}=$ the random specific combining ability (SCA) effect of the $k$ th and $l$ th parents $(k=l$ ) NID $\left(0, \sigma_{S}^{2}\right) ; S^{*} G C A_{i k}, S^{*} G C A_{i l}$, = the random GCA by site interaction $\sim \operatorname{NID}\left(0, \sigma_{T G}^{2}\right) ; S^{*} G C A_{j k l}=$ the random SCA by site interaction effect $\sim$ NID $\left(0, \sigma_{T S}^{2}\right)$ and $R_{i j k l m}=$ the random error term $\sim$ NID $\left(0, \sigma_{T S}^{2}\right)$.

The predominant gene effect in the inheritance of a trait was determined according to the function proposed by Baker (1978):

$2 \sigma_{g c a}^{2} /\left(2 \sigma_{g c a}^{2}+\sigma_{s c a}^{2}\right.$ Equation 2

Where $\sigma_{g c a}^{2}$ is the genetic variance component for general combining ability, and $\sigma_{s c a}^{2}$ is the genetic variance component for specific combining ability.

The narrow sense heritability $\left(h^{2}\right)$ for MFRY, MNR, TFRY, TNR and RBCC was estimated using Equation 3 (Dudley and Moll, 1969):

$h^{2}=\frac{\operatorname{Cov}(G, P)}{\sigma_{p}^{2}}=\frac{\sigma_{G}^{2}}{\sigma_{G}^{2}+\frac{\sigma_{\varepsilon}^{2}}{r l}+\sigma_{G L}^{2}}$..Equation 3

The genotypic variance $\left(\sigma_{G}^{2}\right)$ was computed as:

$\sigma_{G}^{2}=\sigma_{F}^{2}=\frac{M S_{F}-M S_{F L}}{r l} ; \ldots \ldots \ldots .$. Equation 4

Where:

$\sigma_{F}^{2}$ represents the family variance; $M S_{F}$ and $M S_{F L}$ $=$ the mean squares for family and family by location, $\sigma_{e}^{2}=$ the error variance; $\sigma_{G L}^{2}=$ the genotypic by site (environment) variance interaction, represents the number of replicates (blocks) and the number of sites (environments).

SSR-based genetic relationships. For DNA extraction, leaf samples were obtained from the eight parental lines (Monate, Resisto, W-119, Ndou and Khano, Purple_Sunset, Mvuvhelo, 1999_5_1), collected from the glasshouse of ARCVOPI. Two to three leaf discs from the younger leaves were harvested in $2 \mathrm{ml}$ Eppendorf tubes (Sigma-Aldrich, Missouri, USA), and kept in ice for DNA extraction. DNA was isolated using the modified CTAB method, described by Edwards et al. (1991). The DNA concentration for each sample was determined using the nanodrop 1000 ND reader (Thermo Scientific, Wilmington, USA), and compared to three dilutions of $\lambda$ standard DNA (150 ng, $75 \mathrm{ng}$ and $37.5 \mathrm{ng}$ ); and visualised using electrophoresis on $1 \%$ agarose gel containing ethidium bromide (Sigma-Aldrich, Missouri, USA).

The DNA samples were subjected to genotyping, using 20 published SSR markers (Table 2). A $25 \mu \mathrm{l}$ Polymerase Chain Reaction (PCR) containing 0.2 units of MyTaq polymerase (Biogenotype, Massachussetts, USA), 1 x MyTaq reaction buffer $(5 \mathrm{mM} \mathrm{dNTPs}$ and $15 \mathrm{mM} \mathrm{MgCl})$, $0.2 \mu \mathrm{M}$ of forward and reverse primer and $10 \mathrm{ng}$ of DNA was performed for every primer pair. Individual reactions were amplified in the Gene Amp® PCR system 2700 machine (Applied Biosystems, California, USA), with the following conditions: an initial denaturation at $95^{\circ} \mathrm{C}$ for 3 minutes, followed by 35 cycles of denaturation $95^{\circ} \mathrm{C}$ for 15 seconds, primer annealing at optimal temperature for 15 seconds and primer extension at $72{ }^{\circ} \mathrm{C}$ for 20 seconds.

A final extension at $72{ }^{\circ} \mathrm{C}$ for 5 minutes was included. Thereafter, $3 \mu \mathrm{l}$ of $3 \times$ STR loading solution ( $10 \mathrm{mM} \mathrm{NaOH}, 95 \%$ formamide, $0.05 \%$ bromophenol blue, $0.05 \%$ xylene cyanol) was added to each PCR product before electrophoresis through a $3 \%(\mathrm{w} / \mathrm{v})$ agarose gel at 90 Volts for 30 minutes to confirm amplification of each primer alongside a $50 \mathrm{bp}$ and $100 \mathrm{bp}$ ladder [Thermo Scientific, Lithuania (EU)]. Five microlitres of each successful amplicon was further separated on 6\% non-denaturing polyacrylamide gels, for 3 hours at 600 volts and visualised by silver staining. All SSR markers (Table 3) were screened across all genotypes listed in Table 1.

Amplification bands were numbered according to their migration within the gel. It was assumed that bands of the same migration distance in different genotypes, were identical. 
TABLE 1. Origin, yield classification and flesh colour of parental genotypes selected for the study

\begin{tabular}{lllll}
\hline Entry & Line & Flesh colour & Yield & Source \\
\hline 1. & Monate & Cream (C) & High & ARC \\
2. & Ndou & Cream & High & ARC \\
3. & Khano & Orange (0) & High & ARC \\
4. & Resisto & Orange & Low & USA - CIP collection \\
5. & W-119 & Orange & Low & USA - CIP collection \\
6. & Mvuvhelo & Cream & High & ARC \\
7. & Purple sunset & Orange & Medium & ARC \\
8. & 1999_5_1 & Orange & Medium & ARC \\
\hline
\end{tabular}

ARC = Agricultural Research Council of South Africa; CIP = Centro Internacional de la Papa (International Potato Center); USA $=$ United States of America

TABLE 2. Location and environmental conditions of the two experimental sites (Pretoria, Roodeplaat and KwaZulu-Natal, Empangeni) in South Africa during the growing period

\begin{tabular}{lll}
\hline Sites & Roodeplaat & Empangeni \\
\hline Location & 25.604 p S 28.345 p E & 28.725 p S 31.898 p E \\
Planting date & 21 November 2012 & 18 January 2013 \\
Harvesting date & 24 June 2013 & 2 September 2013 \\
Climatic area & Warm temperate & Humid subtropical \\
Altitude $(\mathrm{m})$ & $1168 \mathrm{~m}$ & $105 \mathrm{~m}$ \\
Average temperature (R"C) & 18.3 & 20.3 \\
Total rainfall (mm) & 299.95 & 350.2 \\
Humidity $(\%)$ & 51.7 & 71.1 \\
Soil type & Clay loam & Sandy loam \\
\hline
\end{tabular}

Source: Climatic database ARC-Institute for Climate and Water, South Africa in 2014

For each genotype, the presence of each band was determined and designated " 1 ", and " 0 " when absent. Markers that produced the expected size (100-500 bp) of amplification product were recorded and the polymorphism information content (PIC) calculated using the formula proposed by Roldàn-Ruiz et al. (2000):

$P I C=2 f i(1-f i)$ Equation 5

Where:

$i=$ the marker in study, $f i$ is the frequency of the allele (band) present and $(1-f i)=$ frequency of the null allele. PIC values vary from zero (0) to 0.5 , with zero being the minimum and 0.5 the maximum value.
Binary data were used to generate Nei similarity matrix through the similarity qualitative data (SimQual) function (Sneath and Sokal, 1973) using the Jaccard's similarity coefficient between parental pairs (Mohammadi and Prasana, 2003):

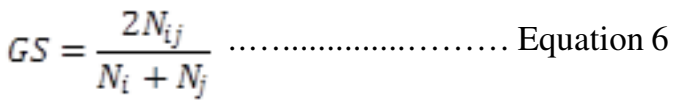

Where:

$N_{i j}=$ the number of bands common to parent $i$ and $j$ and $N_{i}$ and $N_{j}$ the number of bands specific to parent $i$ and $j$, respectively. SSR based genetic diversity $(G D)$ is given as: $G D=1-G S$. Cluster analyses were computed using the unweighted 
TABLE 3. SSR primers pairs used to amplify SSR regions in the DNA of sweetpotato genotypes

\begin{tabular}{|c|c|c|c|c|c|}
\hline Primer name & Primer sequence & Microsatellite repeat & $\mathrm{Ta}^{1}\left({ }^{\circ} \mathrm{C}\right)$ & Expected size & Reference \\
\hline IBSSR18 & $\begin{array}{l}\text { F: GATCTTGAATTAGCCCAC } \\
\text { R: AGATGGATGACCGTATGC }\end{array}$ & $(\mathrm{GA})_{7}(\mathrm{AG})_{5}(\mathrm{GA})_{4}$ & 58 & $90-110$ & Hu et al. (2004) \\
\hline IBSSR19 & $\begin{array}{l}\text { F: GCGAATCAAGTCTTTTGTCCAC } \\
\text { R: GGGACTGTCCTTTGGGTATG }\end{array}$ & $(\mathrm{CA})_{25}$ & 76 & $171-195$ & Hu et al. (2004) \\
\hline IBSSR21 & $\begin{array}{l}\text { F: AAACAACCAACGGGTCTTTGC } \\
\text { R:CTCTAGGGTCGCCATAAAAATCAC }\end{array}$ & $(\mathrm{CA})_{14}$ & 64 & $215-240$ & Hu et al. (2004) \\
\hline IBSSR24 & $\begin{array}{l}\text { F: CCATGCCCTCTGATTGAACG } \\
\text { R: GAACCCAATGAACTTCGCCAC }\end{array}$ & $(\mathrm{GA})_{10} \mathrm{~N}(\mathrm{GA})_{5}$ & 66 & 180-195 & Hu et al. (2004) \\
\hline IBSSR25 & $\begin{array}{l}\text { F: TCTTGCTTCCTAGTCGGCTG } \\
\text { R:CAGGTGAACCAAGTGACCT }\end{array}$ & $(\mathrm{GT})_{15} \mathrm{~T} 2(\mathrm{TG})_{9}$ & 60 & $110-140$ & Hu et al. (2004) \\
\hline IBSSR27 & $\begin{array}{l}\text { F: GTGTTTATCACATCGTTTTCTG } \\
\text { R: GGCTCGTACAATTTTCAAAG }\end{array}$ & $(\mathrm{TA})_{6}(\mathrm{CA})_{16}(\mathrm{TA})_{3}$ & 60 & $120-154$ & Hu et al. (2004) \\
\hline IB-242 & $\begin{array}{l}\text { F: GCGGAACGGACGAGAAAA } \\
\text { R: ATGGCAGAGTGAAAATGGACCA }\end{array}$ & $(\mathrm{CT})_{3} \mathrm{CA}(\mathrm{CT})_{11}$ & 58 & $95-135$ & Buteler et al. (1999); Tumwegamire et al. (2011) \\
\hline IB-248 & $\begin{array}{l}\text { F: GAGAGGCCATTGAAGAGGAA } \\
\text { R: AAGGACCACCGTAAATCCAA }\end{array}$ & $(\mathrm{CT})_{9}(\mathrm{CT})_{8}$ & 62 & $164-177$ & Buteler et al. (1999); Veasey et al. (2008) \\
\hline IB-255 & $\begin{array}{l}\text { F: CGTCCATGCTAAAGGTGTCAA } \\
\text { R:ATAGGGGATTGTGCGTAATTTG }\end{array}$ & $(\mathrm{CT})_{14}$ & 53 & $210-255$ & Buteler et al. (1999); Gwandu et al. (2012) \\
\hline IB-286 & $\begin{array}{l}\text { F: AGCCACTCCAACAGCACATA } \\
\text { R: GGTTTCCCAATCAGCAATTC }\end{array}$ & $(\mathrm{CT})_{12}$ & 50 & $90-122$ & Buteler et al. (1999) \\
\hline IB-297 & $\begin{array}{l}\text { F: GCAATTTCACACACAAACACG } \\
\text { R: CCCTTCTTCCACCACTTTCA }\end{array}$ & $(\mathrm{CT})_{13}$ & 58 & $130-200$ & Buteler et al. (1999) \\
\hline IB-318 & $\begin{array}{l}\text { F: AGAACGCATGGGCATTGA } \\
\text { R: CCCACCGTGTAAGGAAATCA }\end{array}$ & $(\mathrm{CT})_{9 \mathrm{C}}(\mathrm{CT})_{5}$ & 54 & $120-135$ & Buteler et al. (1999); Veasey et al. (2008) \\
\hline IBR-16 & $\begin{array}{l}\text { F: GACTTCCTTGGTGTAGTTGC } \\
\text { R: AGGGTTAAGCGGGAGACT }\end{array}$ & $(\mathrm{GATA})_{4}$ & 58 & $131-237$ & Karuri et al. (2010); Gwandu et al. (2012) \\
\hline IBR-19 & $\begin{array}{l}\text { F: GGCTAGTGGAGAAGGTCAA } \\
\text { R: AGAAGTAGAACTCCGTCACC }\end{array}$ & $(A G)_{5 b}$ & 60 & $190-208$ & Karuri et al. (2010) \\
\hline 690524 & $\begin{array}{l}\text { F: AGGAAGGGCTAGTGGAGAAGGTC } \\
\text { R: AAGGCAACAAATACACACACACG }\end{array}$ & & 57 & $240-315$ & Gwandu et al. (2012) \\
\hline
\end{tabular}

F-Forward primer sequence $\left(5^{\prime}-3^{\prime}\right), R-$ Reverse primer sequence $\left(5^{\prime}-3^{\prime}\right)$, Ta ${ }^{1}$ - optimal annealing temperatures 
pair group method with arithmetic averages (UPGMA) through Numerical Taxonomy Multivariate System (NTSYS-pc) Version 2.21c (Rohlf, 2009).

\section{RESULTS}

Combining ability for $\operatorname{root} \boldsymbol{\beta}$-carotene and yield. The ANOVA of the combined data across the two locations (Table 4), showed highly significant differences $(\mathrm{P}<0.0001)$ among the genotypes for all five traits, (RBCC, MFRY, MNR, TFRY and TNR). Highly significant $(\mathrm{P}<0.0001)$ interactions between genotypes and the environment were observed for RBCC and MFRY $(\mathrm{P}<0.05)$. Both GCA and SCA were highly significant $(\mathrm{P}<0.0001)$ for almost all the traits, except the SCA effect for TNR $(\mathrm{P}<0.05)$. The reciprocal and maternal effects were significant $(\mathrm{P}<0.0001)$ for RBCC (Table 4). The interactions between the GCA, SCA and reciprocal effects with the environment were found in some traits. High narrow sense heritability was observed for all the traits.

GCA effect of the parental lines. GCA effects were highly significant $(\mathrm{P}<0.0001)$ for $\mathrm{RBCC}$, for all parents; and positive GCA effects were observed for orange fleshed parents (Khano, Resisto, W-119) (Table 5). Parents, Monate and Ndou, were good general combiners with positive and significant $(\mathrm{P}<0.01)$ contribution to GCA effect for yield related traits (MFRY, MNR and TFRY). Khano, Resisto and W-119, orange-fleshed breeding lines were not good general combiners, for the yield related traits. Parent W-119 had a significantly negative contribution to the GCA effect for MFRY, MNR, TFRY and TNR. Parental lines, Khano and Resisto had positively significant GCA effect for TNR meaning that these lines contributed to the high number of total roots (Table 5).

SCA effect of the crosses. Majority of the crosses showed more SCA effect for RBCC than any other trait (Table 6). Significant SCA effects were particularly found in crosses involving orangeand cream-fleshed parents. The highest and positive significant SCA effect was found in the combination of W-119 x Monate with $1.69 \mathrm{mg} 100$ $\mathrm{g}^{-1} \mathrm{fw}$. The parents with highest GCA, Khano and Resisto (Table 5), did not necessarily result in the highest SCA when crossed. The cross

TABLE 4. Analysis of variance (mean square values) for combining ability of root $\beta$-carotene content (RBCC), marketable fresh root mass and number (MFRY, MNR) and total fresh root mass and number (TFRY, TNR) across two locations

\begin{tabular}{|c|c|c|c|c|c|}
\hline Source of variation & $\begin{array}{c}\text { RBCC } \\
\left(m g 100 g^{-1} f w\right)\end{array}$ & $\begin{array}{r}\text { MFRY } \\
\left(\mathrm{kg} \mathrm{plant}^{-1}\right)\end{array}$ & $\begin{array}{c}\text { MNR } \\
\left.\text { (roots plant }^{-1}\right)\end{array}$ & $\begin{array}{c}\text { TFRY } \\
\left(\text { kg plant }^{-1}\right)\end{array}$ & $\begin{array}{c}\text { TNR } \\
\left.\text { (roots plant }^{-1}\right)\end{array}$ \\
\hline Genotypes (G) & $39.20^{*+1+k}$ & $0.11^{*+*}$ & $3.03^{* * *}$ & $0.23^{* * *}$ & $7.84^{* * *}$ \\
\hline Environments (E) & $6.98^{* *}$ & $2.47^{\text {t+*t }}$ & $16.68^{*+* x}$ & $5.10^{+ \text {tit }}$ & 0.05 \\
\hline$G \times E$ & $3.27^{4+k}$ & $0.05^{*}$ & 0.87 & 0.06 & 2.45 \\
\hline $\mathrm{GCA}$ & $176.66^{* * * *}$ & $0.21^{* * * *}$ & $6.99^{* * *}$ & $5.89^{* * * *}$ & $23.14^{* * *}$ \\
\hline SCA & $12.20^{* * * *}$ & $0.13^{*+* *}$ & $3.12^{* * *}$ & $3.55^{\text {kn* }}$ & $5.33^{*}$ \\
\hline Reciprocal & $11.20^{* * *}$ & 0.04 & 1.36 & 0.85 & 4.22 \\
\hline Maternal & $9.79^{* * *}$ & 0.01 & 0.54 & 0.22 & 1.72 \\
\hline $\mathrm{GCA} \times \mathrm{E}$ & 2.66 & 0.02 & 0.19 & 0.84 & $8.39^{* *}$ \\
\hline$S C A \times E$ & 2.10 & $0.06^{* *}$ & 0.72 & $1.51^{* *}$ & 1.41 \\
\hline Reciprocal x E & $4.69^{* *}$ & 0.03 & 1.28 & 0.83 & 1.10 \\
\hline Error & 1.22 & 0.02 & 0.77 & 0.05 & 2.19 \\
\hline GCA:SCA & 0.97 & 0.76 & 0.82 & 0.77 & 0.89 \\
\hline $\mathrm{H}$ & 0.96 & 0.75 & 0.94 & 0.77 & 0.99 \\
\hline CV (\%) & 45.78 & 37.72 & 33.22 & 23.17 & 28.88 \\
\hline
\end{tabular}

${ }^{*},{ }^{* *},{ }^{* *}=$ Significant at the $0.05,0.01$ and 0.001 probability levels, respectively. GCA $=$ General combining ability; $\mathrm{SCA}=$ Specific combining ability; $\mathrm{H}=$ Broad sense heritability; $\mathrm{CV}=$ Coefficient of variation; $\mathrm{fw}$ = fresh weight 
combination of Monate $\mathrm{x}$ W-119 was the highest as well as the only one with significant positive SCA, namely for MFRY. No positive and significant SCA effect occured for MNR among the cross combinations. The lowest and significant SCA for MNR and MFRY was observed in the cross Ndou x Monate, despite both being high yielding parents. The lowest significant SCA for MNR and MFRY observed in the cross Ndou x Monate contributed negatively to the yield. The SCA effect in the cross W-119 $\mathrm{x}$ Resisto and the reciprocal cross Ndou $x$ Khano were negative and significant for TNR, which had a contribution in reducing the number of small roots produced by their progenies (Table 6).

TABLE 5. General combining ability effect for root $\beta$-carotene and yield related traits

\begin{tabular}{lccccc}
\hline Parental line & $\begin{array}{c}\text { RBCC } \\
\left(\mathrm{mg} \mathrm{100} \mathrm{g}^{-1} \mathrm{fw}\right)\end{array}$ & $\begin{array}{c}\text { MFRY } \\
\left(\text { kg plant }^{-1}\right)\end{array}$ & $\begin{array}{c}\text { MNR } \\
\left(\text { roots plant }^{-1}\right)\end{array}$ & $\begin{array}{c}\text { TFRY } \\
\left.\text { (kg plant }^{-1}\right)\end{array}$ & $\begin{array}{c}\text { TNR } \\
\left.\text { (roots plant }^{1}\right)\end{array}$ \\
\hline Monate & $-2.24^{* * *}$ & $0.061^{* *}$ & $2.7^{* *}$ & $0.30^{* *}$ & 0.1 \\
Ndou & $-1.42^{* * *}$ & $0.068^{* *}$ & $2.6^{* *}$ & $0.36^{* * *}$ & -0.2 \\
Khano & $1.32^{* * *}$ & $-0.047^{* *}$ & -0.9 & $-0.26^{* *}$ & $0.6^{* *}$ \\
Resisto & $1.46^{* * *}$ & -0.026 & 0.9 & -0.11 & $0.4^{*}$ \\
W-119 & $0.89^{* * *}$ & $-0.056^{* *}$ & $-5.3^{* * *}$ & $-0.28^{* *}$ & $-0.9^{* * *}$ \\
\hline
\end{tabular}

${ }^{*},{ }^{* *},{ }^{* * *}=$ Significant at the $0.05,0.01$ and 0.001 probability levels, respectively; $f w=$ fresh weight; $R B C C=\operatorname{root} \beta$-carotene content; MFRY = marketable fresh root yield; MNR = marketable number of roots; TFRY = total fresh root yield; TNR = total number of roots

TABLE 6. Specific combining ability effect for root $\beta$-carotene and yield related traits

\begin{tabular}{|c|c|c|c|c|c|}
\hline $\begin{array}{l}\text { Crosses } \\
\text { Female x Male }\end{array}$ & $\begin{array}{c}\text { RBCC } \\
\left(\mathrm{mg} 100 \mathrm{~g}^{-1} \mathrm{fw}\right)\end{array}$ & $\begin{array}{c}\text { MFRY } \\
\left(\text { kg plant }^{-1}\right)\end{array}$ & $\begin{array}{c}\text { MNR } \\
\left(\text { roots plant }^{-1}\right)\end{array}$ & $\begin{array}{c}\text { TFRY } \\
\left(\mathrm{kg} \mathrm{plant}^{-1}\right)\end{array}$ & $\begin{array}{c}\text { TNR } \\
\left.\text { (roots plant }^{-1}\right)\end{array}$ \\
\hline Ndou x Monate & 0.18 & $-0.14^{* *}$ & $-0.51^{*}$ & $-0.70^{* *}$ & 0.04 \\
\hline Khano x Monate & $-1.38^{*+* *}$ & -0.05 & $-0.47^{*}$ & -0.31 & -0.68 \\
\hline Resisto x Monate & $-1.33^{\text {t*** }}$ & 0.03 & 0.30 & 0.18 & 0.45 \\
\hline W-119 x Monate & $1.69^{* * *}$ & -0.003 & -0.11 & -0.05 & 0.43 \\
\hline Khano x Ndou & $0.96^{* *}$ & -0.03 & 0.30 & -0.17 & 0.14 \\
\hline Resisto x Ndou & 0.22 & -0.06 & -0.11 & -0.34 & 0.18 \\
\hline Resisto x Khano & 0.19 & 0.04 & -0.04 & 0.24 & -0.15 \\
\hline W-119 x Ndou & $-0.65^{\star}$ & -0.06 & -0.32 & $-0.36^{*}$ & -0.54 \\
\hline W-119 x Khano & 0.29 & 0.03 & 0.03 & 0.18 & -0.31 \\
\hline W-119 x Resisto & 0.13 & $-0.06^{*}$ & $-0.44^{*}$ & -0.33 & $-1.09^{* *}$ \\
\hline \multicolumn{6}{|l|}{ Reciprocal } \\
\hline Monate x Ndou & 0.10 & 0.03 & 0.05 & 0.08 & -0.61 \\
\hline Monate x Khano & $1.05^{* *}$ & -0.03 & -0.10 & -0.16 & 0.19 \\
\hline Monate $x$ Resisto & 0.21 & -0.04 & -0.39 & -0.18 & -0.69 \\
\hline Monate x W-119 & $-1.11^{* *}$ & $0.12^{* *}$ & 0.59 & $0.60^{* *}$ & $0.02^{n}$ \\
\hline Ndou x Khano & $1.59^{* * *}$ & 0.003 & $-0.05^{*}$ & 0.02 & $-1.19^{* *}$ \\
\hline Ndou x Resisto & $-1.34^{* * *}$ & 0.03 & 0.15 & 0.10 & 0.68 \\
\hline Ndou x W-119 & $-0.73^{*}$ & $-0.09^{*}$ & $-0.55^{*}$ & -0.42 & -0.68 \\
\hline Khano x Resisto & 0.45 & $-0.03^{*}$ & -0.49 & -0.15 & -0.27 \\
\hline Khano x W-119 & -0.03 & -0.05 & -0.13 & -0.22 & -0.42 \\
\hline Resisto x W-119 & $-1.36^{*+* x}$ & -0.03 & -0.12 & -0.12 & 0.003 \\
\hline
\end{tabular}

${ }^{*},{ }^{* *}=$ Significant at the 0.05 and 0.01 probability levels, respectively; $f w=$ fresh weight; $R B C C=\operatorname{root} \beta$-carotene content; MFRY $=$ marketable fresh root yield; $M N R=$ marketable number of roots; TFRY = total fresh root yield; TNR = total number of roots 
TABLE 7. Simple Sequence Repeat (SSR) amplification and PIC of 12 SSR markers amplified across eight sweetpotato genotypes

\begin{tabular}{lcccc}
\hline Primers & Total number of alleles & Polymorphic alleles & \% polymorphism & PIC \\
\hline IBSSR 01 & 5 & 5 & 100 & 0.49 \\
IBSSR04 & 7 & 7 & 100 & 0.46 \\
IBSSR07 & 5 & 4 & 80 & 0.39 \\
IBSSR10 & 7 & 7 & 100 & 0.39 \\
IBSSR17 & 6 & 6 & 100 & 0.50 \\
IB-242 & 4 & 3 & 75 & 0.32 \\
IB-248 & 6 & 4 & 66.7 & 0.46 \\
IB-255 & 3 & 2 & 66.7 & 0.10 \\
IB-286 & 6 & 5 & 83.3 & 0.48 \\
IB-297 & 9 & 8 & 100 & 0.49 \\
IB-318 & 6 & 5 & 83.3 & 0.49 \\
IB-R19 & 5 & 5 & 100 & 0.49 \\
Total & 69 & & & - \\
Average & 5.75 & 61 & 87.92 & 0.42 \\
\hline
\end{tabular}

Genetic relationships among parental lines. Out of the 20 SSR markers tested, 12 markers showed positive amplification and scorable alleles (Table 7). A total of 60 alleles (bands) was scored across eight sweetpotato genotypes, with an average of 5.75 alleles per SSR locus. The number of allele varied from three to nine per SSR locus. The Polymorphism Information Content (PIC) (Roldàn-Ruiz et al., 2000) varied from 0.1 to 0.5. For most of the SSR markers, PIC values were above 0.4 .

The UPGMA dendrogram revealed sufficient genetic diversity between the eight genotypes, with a maximum of $60 \%$ similarity observed between two orange-fleshed genotypes, Purple Sunset and Resisto (Fig. 1). The cream-fleshed genotypes (Monate and Mvuvhelo) had the second highest genetic similarity (58\%), further revealing that there was more diversity across genotypes with contrasting morphological features, especially with regards to the â-carotene content (flesh colour).

Genetic similarity and combining ability. Although successful crosses were not obtained between the two most distantly related parents, 1999_5_1 and Monate, the highest and significant MFRY and TFRY was observed among hybrids from the cross between Monate and W-119, also distantly related parents, when Monate was used as the female parent (Table 6). A similar pattern was observed in the SCA effect for RBCC for the cross between Monate and W-119, when W-119 was used as the female. A negative correlation was observed between SCA effect for RBCC and the yield related traits.

\section{DISCUSSION}

Combining ability for root $\boldsymbol{\beta}$-carotene content and yield. The presence of genetic variation among the parental genotypes and progenies across the two locations (Table 4), confirmed the usefulness of diallel crosses in creating genetic variation in the breeding populations of sweet potato. Previous studies in sweetpotato reported high genetic variability resulting from diallel crosses (Kanju, 2000; Chiona, 2010; Zulu et al., 2012), indicating an extensive genetic pool for selection purposes in breeding of a crop (Pierce, 2012).

GCA and SCA effects. The magnitudes of GCA and SCA variances (Table 4) indicated that additive and non-additive gene action were important in determining the inheritance of MFRY, MNR, TFRY, TNR and RBCC. The high GCA:SCA 
ratio observed in the $\beta$-carotene and yield related traits (Table 4), suggests that the additive gene action was predominant over non-additive gene action (Baker, 1978). This confirmed the results reported by Kanju (2000) and Chiona (2009) where additive gene action were predominant in the inheritance of root yield and $\beta$-carotene content in sweetpotato. Although in a different root crop, Da Silva (2008) and Njenga et al. (2014) also reported predominance of additive gene action in the inheritance of cassava. The significant differences observed in the performance of reciprocal crosses for RBCC implied that the maternal effect was involved in determining the magnitude of the trait. The presence of maternal effect is an indication of the cytoplasmic effect (Pierce, 2012), which also confirms the findings by Chiona (2010) on the occurrence of maternal effects in sweetpotato parental lines.

The high broad sense heritability (Table 4) found for all the traits (RBCC, MFRY, MNR, TFRY and TNR) showed that there was a high degree of resemblance between parents and off-springs (Pierce, 2012). Studies by Chiona (2010) and Tumwegamire et al. (2011) also obtained high values for broad sense heritability for fresh root $\beta$-carotene and root fresh yield in sweetpotato. Chiona (2009) found that the broad sense heritability of sweetpotato for $\beta$-carotene was 0.99 and for yield was 0.97 . Tumwegamire et al. (2011) obtained 0.96 for $\beta$-carotene, which conforms with the present findings on the occurrence of high broad sense heritability estimates for $\beta$-carotene content in the root of sweetpotato. Moderate narrow sense heritability for yield related traits was previously reported (Jones, 1986; Kanju, 2000; Martin, 1988), confirming the present findings of low to moderate heritability estimates for yield. In contrast, Ernest et al. (1994) reported high narrow sense heritability for yield, and moderate narrow sense heritability for the number of roots. Thus, high estimates of narrow sense heritability indicate that high response to selection and genetic gains is more likely to be achieved through combining two parents with high GCA effects for RBCC (Pierce, 2012).

Progenies from the crosses with the highest SCA effects are useful in producing superior hybrids (Griffing, 1956). As sweetpotato is a vegetatively propagated crop, progenies displaying genetic gains for a specific trait, can be maintained through stem propagation to retain the genotype superiority (Da Silva, 2008). Selection of the best performing progenies, displaying high SCA effects could potentially result in the identification of a hybrid with superior traits for commercial release at the ARCVOPI. Selection of parents should be based not only on the highest GCA effects, since not all the best general combiners result in highest SCA effects in the progenies. Selection of parents to be included in future breeding programmes should also consider its positive contribution to the SCA effects in the progenies. Therefore, parents should not be discarded solely based on their negative GCA effect, instead, performance of the parent within a cross combination should also be considered during the selection process. Careful consideration oughts to be placed on the role of parents when planning future crosses, as cytoplasmic maternal effects are involved in the inheritance of certain traits such as colour in sweetpotato. Parents displaying the best possible quality of the trait of interest that is influenced by the cytoplasmic maternal effect should then be used as the mother parent.

Genetic relationship among parental lines. The SSR markers used in our study successfully fingerprinted the eight sweetpotato parental lines. Similarly, the study by Gichuru et al. (2005) and Karuri et al. (2010) reported the usefulness and robustness of SSR markers in fingerprinting this polyploid. High genetic variability was found among the lines, which implies the existence of diversity among the parental lines. High diversity has also been found in the sweetpotato collections of East Africa (Gichuru et al., 2005; Tumwegamire et al., 2011; Yada et al., 2010). The high diversity found in sweetpotato is attributed to its high ploidy levels (hexaploid) (Ozias-Akins and Jarret, 1994) and its high outcrossing nature (Shiotani et al., 1990).

\section{CONCLUSION}

High genetic diversity exists among the sweetpotato genotypes in the local sweet potato programme. Genetic analysis is crucial in the selection of genotypes to be used as parental 
lines for improvement of important traits. Hybrids from the crosses between distantly related parental genotypes Monate and W-119 were display high performance in terms of MFRY, TNR and RBCC were selected and included for further field evaluation on new varietal development.

\section{ACKNOWLEDGMENT}

The Agricultural Research Council (ARC) funded the study Owen Sithole College of Agriculture maintained the experiment. Dr Marde Booyse (ARC-Biometry Unit), Ms Tsedal Gebramarian (University of Pretoria) and Prof. Hussein Shimelis (University of Kwa-Zulu Natal) assisted with statistical analysis.

\section{REFERENCES}

Baker, R. 1978. Issues in diallel analysis. Crop Science 18:533-536.

Bertan, I., De Carvalho, F.I.F. and De Oliveira, A.L. 2007. Parental selection strategies in plant breeding programs. Journal of Crop Science and Biotechnology 10(4):211-222.

Bovell Benjamin, A.C. 2007. Sweetpotato: review of its past, present, and future role in human nutrition. Advances in Food and Nutrition Research 52:1-5.

Burgos, G., Salas, E., Amoros, W., Auqui, M., Muñoa, L., Kimura, M. and Bonierbale, M. 2009. Total and individual carotenoid profiles in Solanum phureja of cultivated potatoes: I. Concentrations and relationships as determined by spectrophotometry and HPLC. Journal of Food Composition and Analysis 22:503-508.

Buteler, M., Jarret, R. and Labonte, D. 1999. Sequence characterisation of microsatellites in diploid and polyploid Ipomoea. Theoretical and Applied Genetics 99:123-132.

Buteler, M., Labonte, D., Jarret., R. and Macchiavelli, R. 2002. Microsatellite-based paternity analysis in polyploid sweetpotato. Journal of the American Society of Horticultural Science 127:392 - 396.

Chiona, M. 2010. Towards enhancement of $\beta$ carotene content of high dry mass sweetpotato genotypes in Zambia. Doctor of Philosophy. University of Kwa-Zulu Natal Pietermaritzburg, South Africa.

Da Silva, A.M.Z. 2008. Breeding potential of cassava (Manihot esculenta Crantz) in Mozambique. Doctor of Philosophy. University of the Free State, South Africa.

Dudley, J.W. and Moll, R.H.1969. Interpretation and use of estimates of heritability and genetic variances in plant breeding. Crop Science 9:257-261.

Edward, K., Johnstone, C. and Thompson, C. 1991. A simple and rapid method for the preparation of plant genomic DNA for PCR analysis. Nucleic Acids Research 19:1349.

Edwards, J. and McCouch, S. 2007. Molecular markers for use in plant molecular breeding and germplasm evaluation. Marker-assisted selection: current status and future perspectives in crops, livestock, forestry and fish. Food and Agriculture Organization of the United Nations (FAO), Rome, Italy. 20pp.

Elameen, A., Fjellheim, S., Larsen, A., Rognli, O.A., Sundheim, L., Msolla, S., Masumba, E., Mtunda, K. and Klemsdal, S.S. 2008. Analysis of genetic diversity in a sweetpotato (Ipomoea batatas L.) germplasm collection from Tanzania as revealed by AFLP. Genetic Resources of Crop Evolution 55:397-408.

FAOSTAT, 2012. Food Agriculture Organisation Statistics Online data base. http://faostat.org. Accessed on 06 July 2013.

Griffing, B. 1956. Concept of general and specific combining ability in relation to diallel crossing system. Australian Journal of Biological Science 9:463-493.

Gichuru, V,Aritua, V, Lubega, G, Edema, R., Adipala, E. and Rubaihayo, P. 2005. A preliminary analysis of diversity among East African sweetpotato landraces using morphological and Simple Sequence Repeats (SSR) markers. II International Symposium on Sweetpotato and Cassava: Innovative Technologies for Commercialisation 703:159-164.

Gwandu, C., Tairo, F., Mneney, E. and Kullaya, A. 2012. Characterization of Tanzanian elite sweetpotato genotypes for sweetpotato virus disease (SPVD) resistance and high dry matter content using Simple Sequence Repeat (SSR) markers. African Journal of Biotechnology 11:9582-9590. 
Hwang, S.Y., Tseng, Y.T. and Lo, H.F. 2002. Application of simple sequence repeats in determining the genetic relationships of cultivars used in sweetpotato polycross breeding in Taiwan. Scientia Horticulturae 93:215-224.

Hu, J., Nakatani, M., Lalusin, A.G. and Fujimura, T. 2004. New microsatellite markers developed from reported Ipomoea trifida sequences and their application to sweetpotato and its related wild species. Scientia Horticulturae 102:375386.

Jones, A. 1965. Cytological observations and fertility measurements of sweetpotato (Ipomoea batatas L.). Proceedings of the American Society for Horticultural Science. American Society for Horticultural Science. 86:527.

Jones, A. 1986. Sweetpotato heritability estimates and their use in breeding. HortScience 48:176-184.

Kanju, E.E. 2000. Inheritance of agronomic and quality characters in sweet potato,Doctor of Philosophy. University of Free State, Bloemfontein, Africa.

Karuri, H., Ateka, E., Amata, R., Nyende, A., Muigai, A., Mwasame, E. and Gichuki, S. 2010. Evaluating diversity among Kenyan sweetpotato genotypes using morphological and SSR markers. International Journal of Agriculture and Biology 12:33-38.

Labadarios, D., Swart, R., Maunder, E., Kruger, H., Gericke, G., Kuzwayo, P., Ntsie, P., Steyn, N., Schloss, I. and Dhansay, M. 2007. National Food Consumption Survey-Fortification Baseline (NFCS-FB): South Africa, 2005. Department of Health, Pretoria, South Africa.

Laurie, S.M. and Faber, M. 2008. Integrated community based growth monitoring and vegetable gardens focusing on crops rich in â-carotene: Project evaluation in a rural community in the Eastern Cape, South Africa. Journal of Science of Food and Agriculture 88:2093- 2101.

Laurie, S. M., Van Den Berg, A., Tjale, S.S., Mulandana, N.S. and Mtileni, M.M. 2009. Biofortification program for sweetpotato in South Africa. Journal of Crop Improvement 23(3):235-251.
Lebot, V. 2009. Tropical root and tuber crops: cassava, sweetpotato, yams and aroids, CABI, United Kingdom. 423pp.

Martin, F. 1988. Genetic and physiological basis for breeding and improving the sweetpotato. www.agris.fao.org. Accessed 02/08/2013.

Mohammadi, S. and Prasana, B. 2003. Analysis of genetic diversity in crop plants - salient statistical tools and considerations. Crop Science 43:1235-1248.

Montelaro, J. and Miller, J.C. 1951. A study of some factors affecting seed setting in sweetpotato (Ipomoeas batatas L.) and its progenitors. Euphytica 24:197-208.

Mwanga, R.O.M., Yencho, G.C. and Moyer, J.W. 2002. Diallel analysis of sweetpotato for resistance to sweetpotato virus disease. Euphytica 128:237-248.

Mukherjee, P. and Ilangantileke, S. 2001. Dietary intervention with orange fleshed sweetpotato (Ipomoea batatas $\mathrm{L}$.) to alleviate vitamin A deficiency in South and West Asia. I. International Conference on Sweetpotato. Food and Health for the Future 583:205-210. Musembi, K.B., Githiri, S.M., Yencho, G.C. and Sibiya, J. 2015. Combining ability and heterosis for yield and drought tolerance traits under managed drought stress in sweetpotato. Euphytica 201:423-440.

Nagujja, S. and Yanggen, D. 2005. Post-harvest utilisation of sweetpotato and implications for reducing incidence of Vitamin A deficiency in Uganda. African Crop Science Conference Proceedings 7:663-668.

Njenga, P., Edema, R. and Kamau, J. 2014. Combining ability for beta-carotene and important quantitative traits in a cassava F1 population. Journal of Plant Breeding and Crop Science 6(2):24-30.

Pierce, B.A. 2012. Genetics: A Conceptual Approach W. F. Freeman and Company, New York, USA. 324pp.

Ozias-Akins, P. and Jarret, R. L. 1994. Nuclear DNA content and ploidy levels in the genus Ipomoea. Journal of the American Society for Horticultural Science 119(1):110-115.

Roldàn-Ruiz, I., Dendauw, J., Van Bockstaele, E., Depicker, A. and De Loose, M. 2000. AFLP markers reveal high polymorphic rates in rye 
grasses (Lolium spp.). Molecular Breeding 6:125-134

Rohlf, F. J. 2009 NTSYSpc: Numerical Taxonomy System. Version 2.21c, Exerter Software, Setauket, New York, USA.

Schafleitner, R., Tincopa, L.R., Palomino, O., Rossel, G., Robles, R.F., Alagon, R., Rivera, C., Quispe, C., Rojas, L., Pacheco, J.A., Solis, J., Cerna, D., Kim, J.Y., Hou, J. and Simon, R. 2010. A sweetpotato gene index established by de novo assembly of pyrosequencing and sanger sequences and mining for gene-based microsatellite markers. BMC genomics 11:604614.

Shiotani, I. and Kawase, T. 1987. Synthetic hexaploids derived from wild species related to sweetpotato. Japanese Journal of Breeding 37 (4):367-376.

Shiotani, I., Yoshida, S. and Kawase, T.1990. Numerical taxonomic analysis and crossability of diploid Ipomoea species related to the sweetpotato. Japanese Journal of Breeding 40(2):159-174.

Shisana, O., Labadarios, D., Rehle, T., Simbayi, L., Zuma K., Dhansay, A., Reddy, P., Parker, W., Hoosain, E., Naidoo, P., Hongoro, C., Mchiza, Z., Steyn, N.P., Dwane, N., Makoae, M., Maluleke, T., Ramlagan, S., Zungu, N., Evans, M.G., Jacobs, L., Faber, M. and SANHANES-1 Team. 2013. South African National Health and Nutrition Examination Survey (SANHANES-1). HSRC Press, Cape Town, South Africa.

Shumbusha, D., Tusiime, G., Edema, R., Gibson, P., Adipala, E. and Mwanga, R.O.M. 2014. Inheritance of root dry matter content in sweetpotato. African Crop Science Journal 22(1):69-78.

Sneath, P.H. and Sokal, R.R. 1973. Numerical taxonomy. The principles and practice of numerical classification. Theoretical and Applied Genetics 93(6):613-617.

Tumwegamire, S., Rubaihayo, P., Labonte, D., Diaz, F., Kapinga, R., Mwanga, R. and Grüneberg, W. 2011. Genetic diversity in whiteand orange-fleshed sweetpotato farmer varieties from East Africa evaluated by simple sequence repeat markers. Crop Science 51:1132-1142.
Van den Berg, A.A. and Laurie, S.M. 2004. Cultivation. In: Niederwieser, J.G. (Ed.). Guide to sweetpoato production in South Africa, ARC-Vegetable and Ornamental Plant Institute, Pretoria, South Africa.

Van Jaarsveld, P.J., Faber, M., Tanumihardjo, S.A., Nestel, P., Lombard, C.J. and Benadé, A.J.S. 2005. $\beta$-carotene-rich orange-fleshed sweetpotato improves the vitamin A status of primary school children assessed with the modified-relative-dose-response test. American Journal of Clinical Nutrition 81:1080-1087.

Veasey, E.A., Borges, A., Rosa, M.S., QueirozSilva, J.R., Bressan, E.D.A. and Peroni, N. 2008. Genetic diversity in Brazilian sweetpotato (Ipomoea batatas L., Solanales, Convolvulaceae) landraces assessed with microsatellite markers. Genetics and Molecular Biology 31:725-733.

WHO (World Health Organisation). 2009. Global prevalence of vitamin A deficiency in populations at risk 1995-2005. WHO Global database on vitamin A deficiency. World Health Organisation, Geneva, Switzerland.

Yada, B., Tukamuhabwa, P., Wanjala, B., Kim, D.J., Skilton, R.A., Alajo, A. and Mwanga, R.O. 2010. Characterisation of Ugandan sweetpotato germplasm using fluorescent labelled simple sequence repeat markers. HortScience 45:225-230.

Zhang, D., Cervantes, J., Huamán, Z., Carey, E. and Ghislain, M. 1999. Assessing genetic diversity of sweetpotato (Ipomoea batatas L.) cultivars from tropical America using AFLP. Genetic Resources and Crop Evolution 47:659-665.

Zhang, D., Rossel, G., Kriegner, A. and Hijmans, R. 2004. AFLP assessment of diversity in sweetpotato from Latin America and the Pacific region: Its implications on the dispersal of the crop. Genetic Resources and Crop Evolution 51:115-120.

Zulu, L., Adebola, P., Shegro, A., Laurie S. and Pillay, M. 2012. Progeny evaluation of some sweetpotato (Ipomoea batatas L.) breeding lines in South Africa. Acta Horticulturae 1007:247-254. 